\title{
(5)

\section{På tide med nye referanseverdier og grenseverdier for spirometri}

DEBATT

\section{ARNULF LANGHAMMER}

E-post: arnulf.langhammer@ntnu.no Arnulf Langhammer er dr.med. og spesialist i allmennmedisin, prosjektleder i lungeprosjektet i HUNT og leder i HUNT databank. Han er professor ved Institutt for samfunnsmedisin og sykepleie ved Norges teknisk-naturvitenskapelige universitet og fastlege ved Høvdinggården Legekontor i Steinkjer. Forfatter har fylt ut ICMJE-skjemaet og oppgir ingen interessekonflikter.

\section{SUZANNE CROWLEY}

Suzanne Crowley er dr.med. og spesialist i barnesykdommer, med pediatrisk pulmonologi som spesialfelt. Hun er leder for SPIRO, Legeforeningens interessegruppe for barnelungemedisin, og overlege ved Barneavdelingen for allergi og lungesykdommer, Oslo universitetssykehus. Forfatter har fylt ut ICMJE-skjemaet og oppgir ingen interessekonflikter.

\section{SJUR HUMERFELT}

Sjur Humerfelt er dr.med., spesialist i indremedisin og i lungesykdommer og avtalespesialist ved KALklinikken.

Forfatter har fylt ut ICMJE-skjemaet og oppgir ingen interessekonflikter.

\section{HASSE MELBYE}

Hasse Melbye er dr.med. og spesialist i allmennmedisin. Han er prosjektleder for lungestudiene i Tromsøundersøkelsen, professor i allmennmedisin ved Universitetet i Troms $\emptyset$ - Norges arktiske universitet og leder for Allmennmedisinsk forskningsenhet i Tromsø.

Forfatter har fylt ut ICMJE-skjemaet og oppgir ingen interessekonflikter.

\section{TORBJØRN NAG}

Torbjørn Nag er spesialist i barnesykdommer og overlege ved Klinikk for kvinner, barn og ungdom, Ålesund sjukehus.

Forfatter har fylt ut ICMJE-skjemaet og oppgir ingen interessekonflikter.

\section{ØISTEIN SVANES}

$\emptyset$ istein Svanes er spesialist i lungesykdommer og overlege ved Lungeavdelingen og Yrkesmedisinsk avdeling, Haukeland universitetssykehus.

Forfatter har fylt ut ICMJE-skjemaet og oppgir ingen interessekonflikter.

Det er dessverre uklarheter i valg av referanseverdier og grenseverdier for spirometri. Vi foreslår endringer.

Spirometri er avgjørende i diagnostikk, behandling og oppfølging av pasienter med obstruktiv lungesykdom. Tolkning av spirometri forutsetter vurdering av spirometrikurver, forsert ekspiratorisk volum etter ett sekund (FEV1), forsert vitalkapasitet (FVC) og FEV1/FVC 
(fig 1$)$.

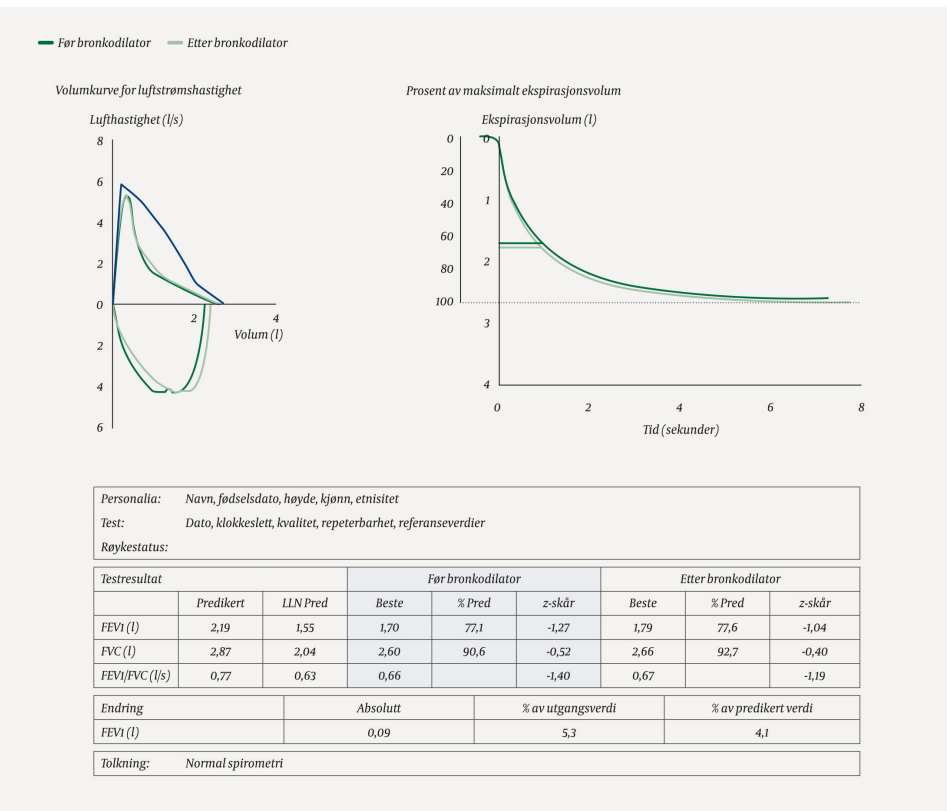

Figur 1 Forslag til utskrift av spirometri. Utover vanlige mål inkluderes LLN Pred (predikert nedre normalgrense), $z$-skår og endring av FEV 1 både i prosent av utgangsverdi og predikert verdi. I stedet for FEV1/FVC LLN = o,70 (GOLD), anbefales GLI-2012 5-prosentil som nedre grense. Hos denne fiktive 76 år gammel kvinnen med høyde $168 \mathrm{~cm}$ er FEV1/FVC o,66. Dette er høyere enn LLN Pred o,63, og zskår-1,45 er større enn -1,65. Kurven er således ikke obstruktiv. Hos yngre personer vil imidlertid tilsvarende hengekøyeform gi mistanke om obstruksjon. Pred = predikert verdi, $L L N=$ nedre normalgrense, $z$-skår $=$ standardisert avvik fra predikert verdi.

\section{Referanseverdier}

For å bedømme spirometri sammenlignes resultatene med referanseverdier basert på et representativt utvalg av friske, aldri-røykende personer. I Norge har det for voksne vært vanligst å bruke referanseverdiene til Quanjer (European Coal and Steal Community, ECSC) (1), Gulsvik (2), Langhammer (3) og Johannessen (4), mens Zapletal (5) og Polgar (6) brukes for barn. Ulike referanseverdier gir store forskjeller i forventede verdier. Man kan få opptil 50 \% forskjell i forventede verdier ved skifte av referansemateriell i 18-20 års alder.

Referanseverdiene beregnes ut ifra etnisitet, kjønn, alder og høyde. Etnisk hvite (kaukasiere) har 5-15\% høyere forventede verdier for FEV1 og FVC enn asiater og afrikanere, mens FEV1/FVC stort sett er uavhengig av etnisitet. Referanseverdiene fra ECSC, Zapletal og Polgar brukes fortsatt, tross kunnskap om at disse underestimerer normal FEV1 og FVC. Dette gir for høy FEV1 og FVC i prosent av forventet, og vil ved kronisk obstruktiv lungesykdom (kols) kunne medføre at pasienter urettmessig ikke oppfyller krav til refusjon av medisiner på blå resept.

Det er godt samsvar mellom ulike referanseverdier utarbeidet i Norge, men disse gir forventede verdier kun for aldersgruppen 18-8o år. Global Lung Function Initiative (GLI) utarbeidet i 2012 nye, multietniske referanseverdier for aldersgruppen 3-95 år basert på data fra 74 ooo friske kaukasiere, afroamerikanere og asiater (GLI-2012)(7). I 2016 konkluderte man i en norsk studie basert på deltagere i alderen 12-8o år fra Troms $\emptyset$ unders $\emptyset$ kelsen ( $n=6$ 437), Hordalandsunders $ø$ kelsen ( $n=2478)$ og HUNT ( $n=21$ 324), med at GLI-2012 passer godt med norske data (8). I Sverige og Finland, derimot, har studier vist at egne referanseverdier passer bedre for voksne enn GLI-2012. GLI-2012 anbefales imidlertid nå av de fleste store internasjonale lungelegeforeninger, også i USA.

Vi anbefaler at GLI-2012 tas i bruk i Norge for alle aldersgrupper og i alle nivåer av helsetjenesten. Dette vil fjerne forvirring relatert til bruk av ulike referanseverdier for ulike aldersgrupper og mellom ulike målesteder samt forenkle forskningssamarbeid om lungefunksjonsdata. 


\section{Grenseverdier}

For biologiske mål defineres vanligvis normalverdier som dem man finner hos $95 \%$ av en frisk befolkning, dvs. gjennomsnittet $\pm 1,96$ standardavvik. Høy lungefunksjon oppfattes ikke som sykelig, og man velger derfor heller å definere nedre 5-prosentil som nedre normalgrense. Bruk av 80 \% av forventet verdi som nedre grenseverdi for FEV1 og FVC er ikke basert på distribusjonen i befolkningen. Variansen i disse målene varierer med alder, bortsett fra i aldersgruppen 15-35 år. For både yngre og eldre vil en grenseverdi ned mot 70-75\% av forventet være riktigere. Den matematiske modellen som brukes i GLI-2012 tar hensyn til variansen av lungefunksjonsmålene relatert til alder og høyde. I tillegg til forventet verdi, estimeres også en nedre normalgrense (lower limit of normal, LLN) og zskår. Sammenligning med nedre normalgrense indikerer om resultatet er normalt eller unormalt, mens z-skår beskriver hvor mange standardavvik målingen avviker fra forventet verdi. Nedre normalgrense definert som nedre 5 -prosentil tilsvarer $z=-1,645$. Disse målene bør inngå i utskrift av spirometri (fig 1 ).

Vi anbefaler at adekvate grenseverdier og avvik fra forventet verdi tas i bruk, dvs. at nedre normalgrense og z-skår inngår i vurderingen av spirometri.

\section{Grenseverdier for kols}

Global Initiative for Obstructive Lung Disease (GOLD) definerer kronisk obstruksjon som FEV1/FVC < o,7o etter bruk av bronkodilator, og dette kriteriet har blitt brukt som spirometrikriterium for kols. Denne aldersuavhengige grenseverdien, som ble valgt for å ha enkle kriterier, samsvarer ikke med fordelingen i en frisk befolkning, der FEV1/FVC avtar med økende alder. Bruk av GOLD-kriteriet bidrar til henholdsvis å underestimere og overestimere forekomsten av kols hos personer under og over 45-50 år. Ved å bruke nedre normalgrense, definert som nedre 5 -prosentil også for FEV1/FVC, vil kols mer presist inkludere personer som har symptomer og behov for behandling. Ingen grenseverdi vil sikkert kunne skille mellom frisk og syk. Det er dermed en forbedring at GOLD nå anbefaler at obstruksjon skal være påvist ved to målinger før kolsdiagnosen stilles.

Alvorlighetsgrad av kols ble tidligere angitt ut fra FEV 1 i prosent av forventet verdi. Ettersom dette korrelerer dårlig med symptomer og livskvalitet, anbefalte GOLD i 2011 en ABCDgradering som i tillegg inkluderte symptombyrde og forverringer. I 2017 ble denne splittet $\mathrm{i}$ en gradering basert på FEV1 i prosent av forventet verdi og $\mathrm{ABCD}$-gruppering kun basert på symptomer og forverringer. Symptombyrde, livskvalitet, forverringer og komorbiditet må vektlegges ved kols. Nytten av gjeldende ABCD-gruppering er imidlertid omdiskutert (9).

Vi anbefaler at estimert 5-prosentil fra GLI-2012 (LLN) innføres som kriterium for obstruksjon i Norge. Dette vil bedre diagnostikken av kols. Inndeling av kols ut fra lungefunksjon har fortsatt verdi, mens nytten av ABCD-gradering er usikker. Forskning bør avklare hvilke variabler og grenseverdier som bør inngå i gruppering av alvorlighetsgrad og risiko.

\section{LITTERATUR:}

1. Quanjer PH, Tammeling GJ, Cotes JE et al. Lung volumes and forced ventilatory flows. Report Working Party Standardization of Lung Function Tests, European Community for Steel and Coal. Official Statement of the European Respiratory Society. Eur Respir J Suppl 1993; 16: 5 - 40. [PubMed][CrossRef]

2. Gulsvik A, Tosteson T, Bakke P et al. Expiratory and inspiratory forced vital capacity and one-second forced volume in asymptomatic never-smokers in Norway. Clin Physiol 2001; 21: 648 - 60.

[PubMed][CrossRef]

3. Langhammer A, Johnsen R, Gulsvik A et al. Forced spirometry reference values for Norwegian adults: the Bronchial Obstruction in Nord-Trøndelag Study. Eur Respir J 2001; 18: 770 - 9. [PubMed][CrossRef] 
4. Johannessen A, Lehmann S, Omenaas ER et al. Post-bronchodilator spirometry reference values in adults and implications for disease management. Am J Respir Crit Care Med 2006; 173: 1316 - 25.

[PubMed][CrossRef]

5. Zapletal A, Paul T, Samánek M. Die Bedeutung heutiger Methoden der Lungenfunktionsdiagnostik zur Feststellung einer Obstruktion der Atemwege bei Kindern und Jugendlichen. Z Erkr Atmungsorgane 1977; 149:343 - 71. [PubMed]

6. Polgar G, Promadhat V. Pulmonary function testing in children: techniques and standards. Philadelphia (Pennsylvania): Saunders Co, 1971.

7. Quanjer PH, Stanojevic S, Cole TJ et al. Multi-ethnic reference values for spirometry for the 3-95-yr age range: the global lung function 2012 equations. Eur Respir J 2012; 40: 1324 - 43. [PubMed][CrossRef]

8. Langhammer A, Johannessen A, Holmen TL et al. Global Lung Function Initiative 2012 reference equations for spirometry in the Norwegian population. Eur Respir J 2016; 48: 1602 - 11.

[PubMed][CrossRef]

9. Soriano JB. Brighter than GOLD. Lancet Respir Med 2018; 6:165 - 6. [PubMed][CrossRef]

Publisert:3. september 2018. Tidsskr Nor Legeforen. DOI: 10.4045/tidsskr.18.0345

Mottatt 20.4.2018, første revisjon innsendt 27.6.2018, godkjent 27.7.2018.

(C) Tidsskrift for Den norske legeforening 2020. Lastet ned fra tidsskriftet.no 